ZAPISKI HISTORYCZNE $\underset{\text { Zeszyt } 3}{\operatorname{TOM}}$ LXXXI - ROK 2016

http://dx.doi.org/10.15762/ZH.2016.66

\author{
SŁAWOMIR JÓŹWIAK \\ (Nicolaus Copernicus University in Toruń) \\ JANUSZ TRUPINDA \\ (Historical Museum of the City of Gdańsk)
}

\title{
TOPOGRAPHY AND SPATIAL LAYOUT \\ OF THE CASTLE OF THE TEUTONIC COMMANDER IN TORUŃ IN THE LIGHT OF MEDIEVAL WRITTEN SOURCESS*
}

Key words: the Middle Ages, medieval architecture in Prussia, the Teutonic Order, Prussia, Teutonic castles, castle

The studies of topography and spatial layout of the Teutonic castle in Torun have now had a long tradition in historiography. The earliest works on the subject, which may be classified as scientific, came to light in the first half of the $19^{\text {th }}$ century. ${ }^{1}$ However, scientists had found it difficult to reconstruct the layout and spatial arrangement of the medieval High Castle of Torun, which was largely destroyed in 1454. It was not until large-scale excavations were held in its ruins in the 1950s and $1960 \mathrm{~s},{ }^{2}$ that numerous unfounded misconceptions and erroneous presumptions in this matter came to be rebutted. On account of the fact that over the last decades the studies have almost exclusively been in the capacity of archaeologists and art historians, the basic method (often the only one) employed by these scientists was a detailed analysis of the preserved walls and architectural detail. However, what has not been accounted for nearly enough are numerous written records containing information on the spatial layout, some of the High Castle chambers, or the topography and the development of the outer castle. And yet these mentions are of

* This article is an English version of the article which appeared in "Zapiski Historyczne", vol. 81, 2016. Translation was part of the task "The publication of 'Zapiski Historyczne' in the English language version, Vol. 81, 2016, books (zeszyt 1-4)" financed as part of the agreement 698/P-DUN/2016 with the resources of the Ministry of Science and Higher Education devoted to the popularization of science.

${ }^{1}$ In the most recent and the comprehensive analysis of the research conducted by scientists of different specialities (historians, archaeologists, art historians) on the history, topography and spatial layout of the Torun Castle in the Middle Ages published in 2011, Adam Chęć had gathered around 100 scientific papers that strictly pertain to this issue, cf. Adam CHĘć, Stan badań i opracowań oraz postulaty badawcze dotyczące zamku krzyżackiego w Toruniu, Archaeologia Historica Polona, vol. 19: 2011, pp. 105-143.

${ }^{2}$ A summary of these studies in: Jadwiga Chudziakowa, Andrzej Kola, Źródła archeologiczne z terenu zamku krzyżackiego w Toruniu, Warszawa-Poznań 1974. 
paramount importance for increasing knowledge about the stronghold of Toruń in the Teutonic era, given that its major part ceased to exist in 1454. Present article will be an attempt to at least partially fill in this gap.

The Teutonic records of the turn of the $15^{\text {th }}$ century classify the Torun Castle in the group of medium strongholds, ${ }^{3}$ which was probably due to the number of brethren-knights and priests in the convent, not the size of the development. Relevant data on this issue is in abundance, but it all dates back to the first half of the $15^{\text {th }}$ century. An inventory list prepared on 8 September 1418 accounts for, together with the commander, the total of 15 brethren (including a master miller from Lubicz and a prosecutor from Old Toruń) with no mention of priests. ${ }^{4}$ Ten years later (31 October 1428) the number of people (together with the superior) in the convent remained the same, yet this time it included two Teutonic clergymen. ${ }^{5}$ In a record of 1437, on the other hand the convent of Torun numbered 17 brethren, including the commander and two priests. ${ }^{6}$ Last but not least, a record drawn up in February 1454 (after the castle had been captured by the insurgents of the Prussian Confederation) listed the total of 15 members together with the commander, possibly one sariant-brother and two clergymen. ${ }^{7}$ The data cited hereinabove document an almost invariable number of friars in the castle over the period of 36 years.

\section{WALLS, GATES AND TOWERS}

When considering all Teutonic brick strongholds in Prussia, the first mention of a castle tower and a stone or brick defensive wall to be spotted in medieval written records, concerns the Torun castle. Two documents dated 10 February 1255, issued by Henry, Bishop of Samland, contain the information that this church official donated 10 grzywnas to the Commander of Torun with the reservation that it may only serve the purpose of erecting a tower and a wall for the castle there. ${ }^{8}$

${ }^{3}$ Geheimes Staatsarchiv Preußischer Kulturbesitz, Berlin-Dahlem, XX. Hauptabteilung, Ordensbriefarchiv (further cit. GStAPK, OBA), no. 556; XX. Hauptabteilung, Ordensfolianten (further cit. GStAPK, OF), no. 3, fol. 382; Sławomir JóźWIAK, Janusz TRuPINDA, Krzyżackie zamki komturskie w Prusach. Topografia i układ przestrzenny na podstawie średniowiecznych źródeł pisanych, Toruń 2012, pp. 52-55.

${ }^{4}$ Das grosse Ämterbuch des Deutschen Ordens, hrsg. v. Walther Ziesemer, Danzig 1921 (further cit. G.A.), p. 436.

${ }^{5}$ GStAPK, OBA, no. 4988; G.A., pp. 441-442.

${ }^{6}$ Das grosse Zinsbuch des Deutschen Ritterordens (1414-1438), hrsg. v. Peter G. Thielen, Marburg 1958, p. 94.

${ }^{7}$ Archiwum Państwowe w Toruniu [State Archive in Toruń] (further cit. APT), Kat. I, Listy i dokumenty, no. 1487III; Andrzej Radzimiński, Janusz TANDeCKI, Katalog dokumentów i listów krzyżackich Archiwum Państwowego w Toruniu, vol. 1: (1251-1454), Warszawa 1994, no. 316.

8 " [...] decem marcas argenti [...] persolui volumus commendatori Thorunensi ita tamen, quod dictam pecuniam preterquam ad turrim perficiendam siue ad murum castri faciendam ad usos alios non convertat [...]" - Codex Diplomaticus Prussicus, hrsg. v. Johannes Voigt, Bd. 1, Königsberg 1836, no. 99, 100. 
Which fragments of this early brick stronghold ${ }^{9}$ could be referred to? If the fragment regards a tower, then it would be tempting to identify it as a massive, detached, octagonal tower situated in the northern part of the High Castle courtyard, especially as there were no other towers within the development of the convent proper (together with the outer baileys). ${ }^{10}$ The problem is that so far all researchers have agreed that the tower hadn't been erected earlier than the first half of the $14^{\text {th }}$ century. ${ }^{11}$ And yet, if the records of 1255 had indeed contained information on the initial stage of constructing a castle brick in Torun, then the erection of the tower within its spatial arrangement would have been perfectly justifiable, as long as the Commander of Torun had in fact followed the bishop's orders. A question regarding its localisation now arises again. Bogusz Wasik has recently developed a thesis claiming that the records of 1255 refer to a partially preserved gate tower located in the northern wall of the nearer outer castle. He pointed out that its archaic architectural features indicate that it may date back to the first half of the $13^{\text {th }}$ century. ${ }^{12}$ The researcher might be right but the fact that the records of 1255 clearly refer to a tower ("turris"), not to a gate may not overlooked.

As regards the castle wall mentioned in the records from 1255, by far the majority of scholars have assumed that it referred to the outer, northern defensive wall of the later outer castle. However, at that time the construction of some of the sections of the enclosing wall for the High Castle is said to have been in progress. ${ }^{13}$ It is hard to tell if that was the case, yet it was highly justifiable (in the day of Prussian uprisings) to enclose the primary High Castle, whose construction was in

\footnotetext{
${ }^{9}$ Marian Arszyński tried to disparage the significance of the 1255 references suggesting that they provide no evidence for the erection of a brick castle in Torun at that time and that towers were "predominantly" wooden, cf. Marian Arszyński, Architektura warowna Zakonu Krzyżackiego w Prusach, [in:] Fundacje artystyczne na terenie państwa krzyżackiego w Prusach, vol. 2: Eseje, ed. Barbara Pospieszna, Malbork 2010, p. 11. Even if we were to admit the researcher's suggestion as regards the tower mentioned in the records, then it would be difficult to agree that the Latin noun "murus" refers to any wooden constructions or fortifications. And he has apparently overlooked this word in the records.

${ }^{10}$ Arthur Semrau believed that the tower referred to in the documents of 1255 was located either within the walls of the south-west, or northern outer castle, but in any case beyond the triangular layout and the outer bailey of the High Castle - Arthur Semrau, Die Anlage und Baugeschichte der Ordensburg Thorn, Mitteilungen des Coppernicus-Vereins für Wissenschaft und Kunst zu Thorn, Bd 24: 1916, pp. 136-137; idem, Das Ordenshaus Thorn, ibid., Bd. 47: 1939, p. 54. Quite apart from the fact that this investigator never supported his thesis with evidence, one might justifiably ask why would the tower be erected in the outer castle in the castle's earliest period?

${ }^{11}$ Cf. Tomasz Torbus, Die Konventsburgen im Deutschordensland Preussen, München 1998, p. 684; idem, Zamki konwentualne państwa krzyżackiego w Prusach, Gdańsk 2014, pp. 64-65, 354; Zbigniew Nawrocki, Zamek krzyżacki w Toruniu. Dzieje budowy, upadek, ponowne zagospodarowanie, Rocznik Muzeum Okręgowego w Toruniu, vol. 13-14: 2005, p. 13; Bogusz WasıK, Budownictwo zamkowe na ziemi chetmińskiej (od XIII do XV wieku), Toruń 2016, pp. 249-251.

${ }^{12}$ B. WAsik, op. cit., pp. 245-246.

${ }^{13}$ Summary of researchers' opinions on the subject so far: Z. NAWrocki, op. cit., pp. 7-10; T. Torbus, Die Konventsburgen, pp. 683-684; idem, Zamki, pp. 62-63; B. WAsIK, op. cit., pp. 245-248.
} 
progress, with at least an external wall as quickly as possible, and that was presumably the primary objective of the works.

The main, octagonal, detached tower ("groser torme;" "der hoge thorm;" "torme;" "thorm") located in the northern part of the High Castle courtyard, which has been dated back to the first half of the $14^{\text {th }}$ century by all scholars so far from, ${ }^{14}$ appears in written records at the end of that century. The earliest mention about it was made in the Torun Commandry inventory list of 20 January 1381. Some of the castle armament was stored in it then. ${ }^{15}$ In the same context, in the list of 30 November 1392 it was referred to as a "great tower" ("grosser torme"). ${ }^{16}$ In a letter of 8 June $1410^{17}$ the deputy Commander of Torun informed the Grand Master about a captured Polish spy, who had been imprisoned in the castle. ${ }^{18}$ Both the wording used ("off dem hawse") as well as the deficiency of towers in the entire Commander's stronghold of Torun (except for the enclosing wall of the western outer castle), suggests that we should consider the discussed tower in this context. Incidentally, one should note that keeping a lay prisoner in such a place would have been exceptional circumstances, ${ }^{19}$ but it might have been due to the significance of the captive and, as mentioned above, the lack of other towers in the topography of the Toruń stronghold.

Particularly interesting in this context is the fragment of a letter written by the Commander of Torun to the Grand Master in the second, or at the beginning of the third decade of the $15^{\text {th }}$ century. Namely, he informed his superior that Daniel, a knight-brother from his convent, was now currently incarcerated on the floor of the castle tower that accessed the passageways with embrasures encircling the wings (three) of the stronghold. The tower in question obviously was the discussed octagonal tower. The Commander explained that he had to lock the said brother Daniel in the tower as he had no other, more convenient place that would serve the purpose. At the same time he requested the Grand Master to show mercy to the prisoner as he had promised to act honestly and commit no offences in the future (presumably against religious acts). The commander was willing to trust him. ${ }^{20}$

${ }^{14}$ See footnote 11 .

${ }^{15}$ G.A., pp. $426-427$.

${ }^{16}$ Ibid., p. 429.

${ }^{17}$ On the dating of this record: Sławomir Jóźwiak, Krzysztof Kwiatkowski, Adam Szweda, Sobiesław Szyвкоwsкi, Wojna Polski i Litwy z zakonem krzyżackim w latach 1409-1411, Malbork 2010, p. 221.

18 "[...] der ich eynen in dem torme off dem hawse czu Thorun habe und den andern heldt der rat in seynen gefengnisse [...]" (GStAPK, OBA, no. 1250).

${ }^{19}$ The most recent study suggests that lay prisoners and captives were not kept in main towers of Teutonic castles, cf. S. JóźwiAK, J. Trupinda, Krzyżackie, pp. 248-256.

20 " [...] her meister! So bitten [!] ich euwer gnade van des bruders Daniels wegen, [der in] dem thorme mittene sitczet als man van der were geet hen yn, wenne ich [in $n$ ]yrne bequemer kunde setczen, wen do hyn. Gnediger her homeister! Das ir im gnedig wolt sein; her hat mir gloubth, das her gar from welde sein und nicht mer gebrechen; als ich hoffe, das her das thuen werde" (GStAPK, OBA, nr 28518). 
The nature of brother Daniel's offence is not known but his place of isolation was situated on top floor (third?) of the Torun castle tower. What might be particularly interesting about this fragment, was the information that at the level of the passageway with embrasures there was a passage between the discussed tower and the (east?) wing of the High Castle. This possibility has recently been accounted for by B. Wasik on the basis of the analysis of architectural records. ${ }^{21}$

A number of very interesting facts relevant for the conducted studies is revealed in the letter from the beginning of January 1420, in which the Commander of Torun notified his superior about the aftermath of the fire that consumed some of the chambers within the stronghold. It turned out that chambers ("kammer") with supplies located between the commander's "gemach" and the tower ("thorm") were burnt, but the armoury of the superior of the Torun convent and his "gemach" were not affected. ${ }^{22}$ Other copious important information contained in the letter will be analysed in detail in the subsequent part of the paper.

The tower in question should now be viewed as an important element of the High Castle topography. It follows from the inventory list of the Torun Commandry of 6 November 1446 that behind it ("hindir dem torme") and on it ("uff dem torme") there were located 4 canons in total. ${ }^{23}$ The protocols written after visitations over the period of 1442-1446 mention that the Commander of Torun made repairs in the castle, which also covered the great tower ("der hoge thorm") ${ }^{24}$ At this point it needs to be emphasised that the main tower of the stronghold of Torun was never referred to as "bergfried" in the written records from the epoch, which name has been erroneously attributed to it by all the scholars so far, ${ }^{25}$ thus contributing to creating a reality that was non-existent in the discussed epoch. Meanwhile, this term, which occasionally appears in the medieval accounts recorded in this area, was exclusively referred to towers (not necessarily made of brick) located in the extreme, outer defensive lines of the outer castle. ${ }^{26}$

${ }^{21}$ B. WAsIK, op. cit., p. 251.

22 "[...] so thu ich euch czu wissin, das von euwirm gemache bis an den thorm, do vorath off leit, dy kammer gancz abgebrant sint, ydoch an euwirm harnisch noch gemache keyn schade ist gescheen [...]" (GStAPK, OBA, no. 3094; Acten der Ständetage Preussens unter der Herrschaft des Deutschen Ordens, hrsg. v. Max Töppen, Bd. 1-5, Leipzig 1878-1886 (further cit. Acten), here: Bd. 1, no. 283).

${ }^{23}$ G.A., pp. $458-460$.

24 "Das hus ist och bufellig, idoch so hot der kompthur gebuwet bede borne, den hogen thorm und dy brucke vor dem huse" (Visitationen im Deutschen Orden im Mittelalter, Teil 1: 1236-1449, hrsg. v. Marian Biskup, Irena Janosz-Biskupowa (Quellen und Studien zur Geschichte des Deutschen Ordens, Bd. 50) (further cit. Visitationen), Marburg 2002, no. 115, p. 200.

${ }^{25}$ T. Torbus, Die Konventsburgen, pp. 301-302, 679; idem, Zamki, pp. 65, 353-354; Adam CHĘć, Wieże główne w zamkach krzyżackich, Acta Universitatis Nicolai Copernici, Archeologia (2001), vol. 28, pp. 169-179; Kazimierz Pospieszny, „Castrum Thorun” po 1300 roku a „klasyczny” model zamku komturskiego w Prusach, [in:] Sztuka w kręgu władzy. Materiały LVII Ogólnopolskiej Sesji Naukowej SHS, ed. Elżbieta Pilecka, Katarzyna Kluczwajd, Warszawa 2009, p. 83.

${ }^{26}$ More on the subject: S. Jóźwiak, J. Trupinda, Krzyżackie, pp. 234-237; Sławomir Jóźwiak, Krzyżacki murowany zamek komturski w Kłajpedzie w świetle średniowiecznych źródeł pisanych, Klio. Czasopismo poświęcone dziejom Polski i powszechnym, vol. 32: 2015, pp. 8-10, 13-15, 19-20. 
Regrettably, medieval written records (apart from the documents of 1255 cited above) do not provide information on the enclosing wall of the Torun Castle. There are, however, but a few mentions of a gate (presumably the main gate) located in the western wing of the convent proper. It was mentioned in the inventory list of 30 November 1392 that "above on the gate" ("oben off dem tore") garments, fabric and large amounts of food (meat, cheese, butter) were stored. ${ }^{27}$ This information is interesting in so far as the scholars have not been in a position to say anything substantial about this gate of the Torun Castle, claiming that it was a single-storey development, ${ }^{28}$ which can be hardly corroborated in the light of the sources quoted. With the Malbork castle being a model, it was managed by a separate Teutonic official, "Tormeister," mentioned for the first time in the inventory list of 8 September $1418 .{ }^{29}$ The information on the placement of two large cannons in the outer bailey contained in the inventory list of the Torun Commandry issued on 6 November 1446 may have referred to the direct vicinity of the gate. ${ }^{30}$ Moreover, the abovementioned protocols prepared after visitations over the period of 1442-1446 contain a mention of a bridge in front of the castle that required repair. ${ }^{31}$ Perhaps a reference was made to a drawbridge which linked the Torun High Castle with the outer castle. ${ }^{32}$

\section{TOPOGRAPHY AND THE SPATIAL LAYOUT OF THE HIGH CASTLE}

As it was in the case of information presented in the documents of 1255 about the wall and the tower of the discussed stronghold, a mention of the erection of a Torun Castle Temple is also chronologically the oldest entry in the existing written records in relation to all other Teutonic strongholds of this type in the State of the Teutonic Order. In a document issued in March 1263, Anselm, the Bishop of Warmia, in the capacity of a papal legate, granted indulgence to those who would be involved in the construction of a chapel ("capellam") "anew" ("de novo") in that castle in honour of the Crucified ("in laudem crucifixi"), initiated by the Commander of Torun and the brethren. ${ }^{33}$ In this case a number of questions also arises. For instance, what could be the significance of the erection "anew" or perhaps

${ }^{27}$ G.A., p. 429.

${ }^{28}$ Summary of the knowledge on the subject so far: T. Torbus, Die Konventsburgen, pp. 680, 687-688.

${ }^{29}$ G.A., pp. $435-436$.

${ }^{30}$ Ibid., pp. $458-460$.

31 "Das hus ist och bufellig, idoch so hot der kompthur gebuwet bede borne, den hogen thorm und dy brucke vor dem huse" (Visitationen, Teil 1, nr 115, s. 200).

${ }^{32}$ Arthur Semrau presumed the existence of a bridge on the eastern side of the outer castle, cf. A. Semrau, Das Ordenshaus Thorn, p. 59. However, he was not able to prove it.

${ }^{33}$ Codex Diplomaticus Warmiensis oder Regesten und Urkunden zur Geschichte Ermlands, hrsg. v. Carl P. Woelky, Johann M. SAAge, Bd. 1, Braunsberg 1860 (further cit. CDW), no. 45. 
"from scratch"? Is it a reference to a temple which was later located on the first floor, in the eastern part of the southern wing of the High Castle, and does the information in the source indicate that invocation is real? It appears that it refers to the proper chapel of the brick castle. Would that mean, as suggested by Tomasz Jasiński, that the construction of the stronghold itself, surrounded by an enclosing defensive wall, was coming to an end? ${ }^{34}$ The scholar's attention was drawn to the fact that the erection of the brick castle in Torun (comprised at this stage of the enclosing wall and the residential and utility southern wing $)^{35}$ had been completed by 1276 at the latest, as the information that the brickyard providing for the castle and both towns (the old and the new) was handed over to the local Franciscans for a temporary use comes from this period. ${ }^{36}$ Meanwhile, art historians and archaeologists, with no recourse to the abovementioned source record from 1263, only on the basis on the analysis of the architectural detail, date the chapel back to $1270 \mathrm{~s}$ or $1280 \mathrm{~s} .{ }^{37}$ There is no doubt, however, that it existed in 1296 . This fact is proven by a document issued on 17 May that year whereby Konrad Stange, the Commander of Toruń, granted gardens to local millers, whose list of witnesses included "frater Fridericus custos capelle eiusdem domus." ${ }^{38}$

Scholars who have been studying the castle have so far disregarded the document issued on 9 February 1262 by Helmerich von Würzburg, a special representative of the Grand Master for Prussia and Livonia, under which an exchange of goods between Torun and Teutonic Knights could be carried out. The latter, among others, were to receive a rent in the amount of 7 grzywnas from the mill by the Torun Castle ("von der mulen under der burch ze Thorun"). ${ }^{39}$ It is the first Prussian document ever to have been issued in German. Both the content of the extract quoted above, and the place of issuance of the certificate, together with the use of the noun "burch" ("castle"), ${ }^{40}$ which had not been used in the State of the Teutonic Order until the beginning of the $14^{\text {th }}$ century, clearly indicate that at

${ }^{34}$ Tomasz JAsı́́ski, Powstanie zamku krzyżackiego w Toruniu, [in:] Historia Torunia. W czasach średniowiecza (do roku 1454), ed. Marian Biskup, Toruń 1999, p. 140.

${ }^{35}$ However, B Wasik, for instance, on the basis of architectural data, believes that in 1260s the curtain wall of the High Castle had already been erected in its entirety, cf. B. WASIK, op. cit., pp. 246-248.

${ }^{36}$ Preußisches Urkundenbuch. Politische Abteilung, hrsg. v. August Seraphim, Bd. I, Hälfte 2, Königsberg/Pr. 1909 (further cit. Pr.Ub. I/2), no. 342; T. Jasıński, Powstanie, p. 140.

${ }^{37}$ Jerzy Frycz, Gotycka architektura Torunia, [in:] Sztuka Torunia i ziemi chetmińskiej 12331815, ed. Józef Poklewski, Warszawa-Poznań-Toruń 1986, p. 34; T. Torbus, Die Konventsburgen, pp. 683-684; Z. NAWrocki, op. cit., p. 11; B. WASIK, op. cit., pp. 247-249. Earlier, without providing any evidence, A. Semrau accepted that the construction of this chapel was completed by 1264 (A. Semrau, Das Ordenshaus Thorn, p. 55).

${ }^{38}$ Pr.Ub. I/2, no. 661.

${ }^{39}$ APT, Kat. I, no. 5; Pr.Ub. I/2, no. 156.

40 "[...] ist gegebin [...] zu Thurun in der burch" (ibid.). On the manner of determining Teutonic castles and their individual parts in medieval written records cf. S. JóźwIAK, J. TrupINDA, Krzyżackie, pp. 65-107. 
some point the stronghold of Toruń, presumably surrounded by a stone defensive wall (referred to in the documents of 1255), had been ready. Unfortunately, its original development and the spatial layout of the interior remain a mystery, yet, as mentioned before, the chapel (which one?) started to be erected the following year (1263). ${ }^{41}$

One of the most important utility chambers of each Teutonic castle in Prussia made of brick was a dining room, or a refectory. In the topography of the Torun stronghold there were at least two such rooms. However, the difficulty is that the extracts in medieval written records do not clarify which one is being discussed at a given moment. In order to provide a complete picture of this issue, let us start these deliberations from the end.

In the letter written on 13 August 1453, the Commander of Torun notified the Grand Master that the councillors of the New Town, together with other people who left the Prussian Confederation, spent the night of 11 of August in the castle ("im hauwße"), where they fled after having been warned by "good friends" about their possible assassination. The commander hosted them in the "old refectory" 42 where they could sleep the night. ${ }^{43}$ This account clearly proves that there must have been at least two refectories within the entire stronghold of Torun. By the term "old refectory" (i.e. built the earliest) one would have to understand the one in the convent of the High Castle. Nevertheless, it is rather striking that the commander gave over this particular chamber to lay fugitives to serve as their bedroom. In any case, it seems that also in this refectory ("in estuario maiori commendatoris castro Thorun") situated in the High Castle, on 12 February 1419, a notarial instrument was drawn up which summarised the mutual agreements and the manner in which all the undertaken engagements terminating the conflict between Jan Kropidło, the Bishop of Włocławek and the Order would be fulfilled. ${ }^{44}$ The season of the year (winter) and the nature of the refectory ("estuarium maius" ${ }^{45}$ ) would indicate that it was heated by a heat-storing, earthen chamber furnace operating in the system traditionally known as "hypocaustum." 46 The use of the term "larger"

${ }^{41}$ Cf. above.

42 "Also goben wyr en das alde Rempther in im hawße; dorinne sy sich dy nacht obir enthilden."

${ }^{43}$ GStAPK, OBA, no. 12306.

${ }^{44}$ GStAPK, XX. Hauptabteilung, Pergamenturkunden (further cit. GStAPK, Perg. Urk.), Schiebl. LIII 45.

${ }^{45}$ In reference to Teutonic castles, the noun "estuarium," used in some notarial instruments drawn up in Latin, without fail referred to a dining room heated with a heat-storing, earthen chamber furnace operating in the "hypocaustum" system - for a summary of the findings on the subject see also: Sławomir Jóźwiak, Janusz Trupinda, Miejsca wystawiania instrumentów notarialnych w przestrzeni zamku malborskiego $w$ XIV $i$ w pierwszej połowie XV wieku, Zapiski Historyczne (further cit. ZH), vol. 77: 2012, no. 2, pp. 12-16; idem, Krzyżackie, p. 149 f.

${ }^{46}$ Medieval written records, in combination with archaeological discoveries made so far provide an unquestionable proof that in the case of Teutonic high castles in Prussia, refectories situated in the representational part of the floor were typically heated with that kind of furnaces, cf. S. JóźwiAK, J. Trupinda, Krzyżackie, pp. 146-168, 261-264, 310-342. 
in reference to this room allows the interpretation that within the discussed castle (together with the outer castle) there must have been a "lesser" room of this kind. ${ }^{47}$

Whereabouts in the spatial layout of the Torun castle should the convent's refectory be sought? Nearly all scholars so far have located it near the church, on the southern wing floor. ${ }^{48}$ If we were to accept the suggestions of some scholars about the existence of relics of an earthen, heat-storing furnace on the ground-floor of the eastern wing ${ }^{49}$ then on its first floor, north of the church, the refectory would indeed be located, rather than a chapterhouse, which has so far been unanimously assumed by scholars, but the evidence for which has never been found in the discussed stronghold. ${ }^{50}$ However, one more issue should be additionally signalled here. Namely, the eastern wing of the High Castle in Torun was not going to be built until the first half of the $14^{\text {th }}$ century. ${ }^{51}$ Where would the dining room (refectory) have been located earlier, in the second half of the $13^{\text {th }}$ century, when the High Castle's development was restricted only to one southern wing? Perhaps it was located on the upper floor, in the room that was adjacent to the chapel-church from the west. If that was the case, the room would have had to lose its originally intended purpose. There is no evidence that brick, Teutonic, commander strongholds in Prussia, within the spatial layout of their High Castles, housed two refectories at the same time. ${ }^{52}$

This does not exhaust information on dining rooms within the stronghold of Torun in medieval written records. What is worth considering is the report from the conquest of the city of Inowrockaw by Teutonic troops of 3 September 1431, and its castle on the following day, which, although preserved in its original form and made into three copies in Latin and German (complete with an attached list of captives), has been ignored by archaeologists and art historians. The captives' names were written down and they were obliged to report in six weeks counting from 4 September (i.e. 16 October) "ken Thorun uff das haws in den Remther

${ }^{47}$ But its location should be sought outside the space of the High Castle, cf. further.

${ }^{48}$ T. Torbus, Die Konventsburgen, s. 679; idem, Zamki, pp. 56, 66 (with certain doubts); Z. NAWrocki, op. cit., pp. 11-12; K. PospieszNy, „Castrum Thorun”, p. 82 f. In another way S. Jóźwiak, J. TrupindA, Krzyżackie, pp. 330-331; B. WAsiK, op. cit., p. 252.

${ }^{49}$ T. Torbus, Die Konventsburgen, pp. 679-680; Z. NAwrocki, op. cit., p. 14; Barbara PospiesZNA, "Urządzenia grzewcze zamków krzyżackich w Prusach. Zabytki sztuki i kultury życia codziennego", part. 2, Torun 2007 [typescript in the UMK library].

${ }^{50}$ The room referred to as a "chapterhouse" within the spatial layout of Teutonic castles in Prussia was contrived by German scholars in the first half of the $19^{\text {th }}$ century. However, in medieval written records there is no mention of such interiors at all, cf. S. Jóźwiak, J. Trupinda, Krzyżackie, pp. 310-326.

${ }^{51}$ This belief is held by all contemporary scholars. Summary of the knowledge on the subject so far: T. ToRbus, Die Konventsburgen, pp. 684, 686; idem, Zamki, pp. 62, 64-65; B. WAsıк, op. cit., pp. 251-252.

${ }^{52}$ Cf. S. JóźWiak, J. Trupinda, Krzyżackie, pp. 310-342; iidem, Czy średniowieczne źródła pisane maja znaczenie w badaniach nad zamkami krzyżackimi w Prusach?, ZH, vol. 80: 2015, no. 1, p. 104. 
(refectorium).".53 At a first glance, this refers to the refectory in the convent of the High Castle. However, would several dozen captives have been allowed in there? It is much more likely they would have had to turn up in the more easily available refectory that would be located outside the main area of the High Castle. Besides, analogical information concerning the events to come later is present in other medieval written records. As it is apparent from a Teutonic roll of late September 1454, Polish captives from the battle of Chojnice (8 September) were mostly to report in Malbork in the Grand Refectory (in the western wing of the compact construction of the first, internal outer castle) on 11 November that year. ${ }^{54}$ In Torun in 1431 it must have been similar. The captives from Inowrocław were to turn up in the refectory, but not the one which was located in the High Castle, but the one beyond the area of the main convent (either within the area of the commander's "gemach" in the western outer bailey, or, which is less likely, in one of the facilities in the western part of the outer castle). ${ }^{55}$ The existence of the second refectory is indirectly proven also by chronicle records relating to the events of 18 December 1433. It was when the representatives of the states set out for the Torun Castle "auff des komethurs gemach" to participate in the talks with the Grand Master and church dignitaries in order to persuade them to make peace with Poland. ${ }^{56}$ For such a meeting to take place in the commander's "gemach" a larger, heated room (end of December) was required. In all likelihood it was the refectory located therein..$^{57}$

Medieval written records also provide a source of a detailed arrangement of service and utility rooms within the castle area. Important information on the subject has been contained in the abovementioned letter of the Torun Castle Commander to his direct superior from early January 1420, in which the Teutonic official notified him about the losses made in consequence of a fire. In the aftermath of the fire the rooms in the northern part of the western wing (only on the ground floor?) in the convent proper were burnt (between the commander's "gemach" in the outer bailey and the tower in the courtyard of the High Castle). The author claimed to have lost all his oat and hay in the fire, whereas his superior had lost some beaver hide "eyne bewerynne hawt"). Additionally, some bedclothes ("bettecleydir") and other equipment belonging to a tailor who was working (living?)

${ }^{53}$ GStAPK, OBA, no. 5762.

${ }^{54}$ Ibid., no. 13408; Marian Biskup, Spisy jeńców polskich z bitwy pod Chojnicami, Przegląd Historyczny, vol. 56: 1965 , no. 1 , p. 88 f.

${ }^{55}$ For the location of the commander's "gemach" within the Torun Castle area cf. further.

${ }^{56}$ Die ältere Hochmeisterchronik, bearb. v. Max TöPPEN, [in:] Scriptores rerum Prussicarum, hrsg. v. Theodor Hirsch, Max Töppen, Ernst Strehlke, Bd. 3, Leipzig 1866, p. 638.

${ }^{57}$ Whereby dubbing it as a "new refectory" ("der neue Remter") by A. Semrau is but an overuse, as this name never appeared in medieval written records. The scholar was attempting to find it (just as the commander's "gemach") in the northern or western wing of the High Castle, which is unacceptable, cf. A. Semrau, Das Ordenshaus Thorn, pp. 62-65. 
within the high castle area. ${ }^{58}$ However, no information about the losses in cereals (rye, wheat) would indicate that they had been stored in the attic of the two main wings of the Torun convent - the southern and eastern wing, in a manner similar to other commander castles. ${ }^{59}$ And these were not affected by the fire.

Written records from 1424 onwards, among other utility rooms located within the area of the discussed high castle, refer to a convent kitchen ("coventskochen"; "kuchen uff dem huwsze"). ${ }^{60}$ This more accurate term was applied in this case so as to differentiate it from the kitchen that the commander had at his disposal in his "gemach." ${ }^{61}$ Additionally, in the inventory list of the commandry drawn up on 7 January 1397 there was the abovementioned "tresil" ("treasury") in which, according to the list, silver crockery was kept. ${ }^{62}$ Sadly, there are no hints as to its location, and the two likely venues would be the area of the convent proper (of the high castle) and the commander's "gemach" within the outer bailey.

\section{TOPOGRAPHY AND DEVELOPMENT OF THE OUTER BAILEY AND THE OUTER CASTLE ${ }^{63}$}

Medieval written records provide a different picture of the development of the outer castle in the Torun stronghold than it was assumed in historiography ${ }^{64}$ The negotiations as regards the compensation for war damages for the Polish king Casimir the Great on 31 March 1339 were held by papal nuncios Galhard of Carcès

${ }^{58}$ GStAPK, OBA, no. 3094; Acten, Bd. 1, no. 283.

${ }^{59}$ Such a manner of storing cereal is corroborated by medieval sources with respect to other Teutonic castles, cf. S. JóźwiAK, J. TrupindA, Krzyżackie, pp. 415-420.

${ }^{60}$ G.A., p. 439 f. Scholars have so far been locating the convent kitchen in the western part of the southern wing of the high castle in Toruń, cf. T. Torbus, Die Konventsburgen, p. 679; Z. NAwrockI, op. cit., pp. 12-13; B. Pospieszna, op. cit.; B. WAsik, op. cit., p. 248. However, in reality there is no sound evidence to prove such a location.

${ }_{61}$ "Die komthurs kuche und uff den meister und allerley gasterye myt gebietigern. summa 53, 5 mr., 23 den." (Marian Biskup, Materiały do dziejów komturstwa toruńskiego z lat 1447-1448, Rocznik Toruński, vol. 34: 2007, p. 152). According to this source fragment, which is a record of the commander's revenues and expenses in the period of 1447-1448, this kitchen was where meals were prepared for the Grand Master paying a visit to the local commander, church dignitaries and other unknown guests. One might presume that it was located beside the "gemach" belonging to the commander of the convent of Torun. And it was probably in his refectory where meals were consumed.

62 "Item dis nochgeschreben silberynne gerete ist im tresil czu Thoron: czum ersten 2 flederynne koppe mit silber beleget, item 14 silberynne koppe mit hogen dirhaben fussen, item 1 par silberynne becken, item 1 silberynne kanne, item 2 horner mit silber beslagen” (G.A., pp. 430-431).

${ }^{63}$ Contemporary scholars have a tendency to multiply the outer castle areas in Toruń. Zbigniew Nawrocki, without including the outer bailey, speaks of three: Upper, Lower and Northern. T. Torbus on the other hand refers to an Upper, Lower and “Third”, cf. Z. NAwrocki, op. cit., pp. 20-24; T. TorBUs, Die Konventsburgen, pp. 681-682. However, in relation to the discussed era such nomenclature is anachronistic. Medieval written records made use only of the term "outer castle," without any adjectival specification. Therefore, the authors of this article keep to this nomenclature.

${ }^{64}$ Cf. A. Semrau, Das Ordenshaus Thorn, pp. 53-85; T. Torbus, Die Konventsburgen, pp. 681-683; Z. NAwrocki, op. cit., pp. 18-24; K. Pospieszny, „Castrum Thorun”, pp. 75-89. 
and Peter, son of Gervase, with the Grand Master "in preurbio castri Thorun Culmensis dyocesis," ${ }^{\prime 65}$ which is revealed by the content of the notarial instrument drawn up by them on that occasion. The season, witnesses (around 20), the use of the noun "preurbium"66 (for the first time in known documents of that sort) all these facts would be compelling to claim that at that time there could have existed a facility in the outer castle ("gemach" of the convent's superior?), with a relatively large room, to be used for these negotiations. Regrettably, not much more can be said on the subject. It is only the information in the written records drafted as of 1380 s that may lead to the conclusion that in the outer castle and the western outer bailey of the Torun Castle there were several important residential and utility facilities.

The first solid piece of evidence for admitting the veracity of this observation appears in the vidimus of 22 April 1388, whereby the Grand Master Konrad Zöllner von Rotenstein ordered to confirm the settlement that was reached by Polish and Teutonic negotiators. This document was issued "in aula estiuali in suburbio castri Thorun sita Culmensis diocesis." ${ }^{\prime 7}$ When accounting for the Latin noun "aula" 68 one may conclude that the vidimus was drawn up in the "summer refectory" located in the outer castle. However, a question arises whether the room may indeed be referred to as a "refectory." The doubt arises from the fact that in the State of the Teutonic Order in Prussia, at least until the end of the Thirteen Years' War (until 1466), none of the preserved written records (Latin or German) contains evidence for the existence of "summer refectories" within Teutonic high castles or outer castles. The same observation, against a contrary opinion of Marc Jarzebowski, also refers to Episcopal and Capitular castles. ${ }^{69}$ However, there was an abundance of the so-called summer houses (or "chambers"), which were located within the development of the outer castle. ${ }^{70}$ It seems that the name of the cham-

${ }^{65}$ Pr.Ub. III/1, hrsg. v. Max Heın, Königsberg/Pr. 1944, no. 233.

${ }^{66}$ To become acquainted with the use and meaning of the nouns "preurbium" and "suburbium" in notarial instruments issued in $14^{\text {th }}$ and $15^{\text {th }}$ centuries in the territory of the State of the Teutonic Order in Prussia see: S. Jóźwiak, J. TrupindA, Krzyżackie, pp. 76-84, 116 f.

${ }^{67}$ GStAPK, Perg. Urk., Schiebl. 76, no. 26.

68 "Aula" - manor, palace, castle, large room, chamber, seat - Cf. Aula, [in:] Stownik łaciny średniowiecznej w Polsce, ed. Marian Plezia [et al.], Wrocław-Kraków-Warszawa 1953-2009 (further cit. M. Plezia, Słownik), here: vol. 1, pp. 954-955.

${ }^{69}$ When writing about the documents being issued in summer refectories of Episcopal castles, this scholar cites sources where such rooms are not even mentioned, cf. Marc JarzeBowski, Die Residenzen der preußischen Bischöfe bis 1525, Torun 2007, pp. 85, 88. A "pallacium estivale" in the castle (manor?) of the Bishops of Warmia in Ornet that appears in the certificate of 1 April 1348 (CDW, Bd. 2, Mainz 1864, no. 105) does not need to be a "summer refectory." In any case, neither the name used in the source, nor the nature of this residential stronghold, would suggest that. Only "aula aestivalis" in the castle of the Bishops of Pomezania in Prabuty, mentioned in the narrative of the year 1487, could in fact play the role of the refectory, cf. M. JARZEBOwsKI, op. cit., pp. 57-58. This, however, is not that certain.

${ }^{70}$ More on the subject in: S. JóźwiaK, J. Trupinda, Krzyżackie, pp. 168-177. 
ber that appears in the vidimus of 1388 ("aula estiualis") should be translated as a "summer chamber."

Luckily, records that point to the approximate location of the building or the chamber within the castle area have been preserved. It is a fragment of an account drawn up shortly after signing the Treaty of Torun, most likely directly after 9 July $1411^{71}$ where the Teutonic management collected a fair number of accusations directed at Jan Kropidło, the Bishop of Włocławek, for his hostile and treacherous attitude towards the Teutonic Order during the second, decisive phase of the war with Poland and Lithuania between July 1410 and the beginning of 1411. The source includes a fragment that gives an account of a visit that the bishop made on 29 June 1410 in the "gemach" of the Torun castle, occupied then by the Grand Master, where, with his arms raised and tears welling in his eyes he swore on God, his loyalty and honour that as long as he remained alive, he would never have stood against the Teutonic Knights, and always show them his allegiance and love by his words and deeds. ${ }^{72}$ After this solemn declaration had been made, the Order's superior took the bishop by the arm and took him from the "gemach" in which he had been residing towards the Vistula river (going outside?) to the "summer house" ("somerhaws"), where all the Teutonic dignitaries, members of the Grand Master's Council, were gathered then. They were notified about Jan Kropidło’s obligation, which was warmly welcomed. ${ }^{73}$ Whereabouts in the topography of the Torun Castle was the mentioned "summer house" located? The starting point of our quest for the answer to this question is determining in which "gemach" the Grand Master resided in 1410. The meaning of the German noun used in the account $^{74}$ rules out its location within the area of the High Castle. Therefore, the only remaining possibilities are the outer bailey and the outer castle. It is possible then that the highest superior of the Order was hosted by the Commander of Torun in his own "gemach," which was probably located in the Western outer bailey, north of the High Castle's entry gate. ${ }^{75}$ If that is the case, they would have passed through

${ }^{71}$ Antoni LiedtKe, Walka księcia Jana Opolskiego „Kropidly” z Krzyżakami w obronie majątkowych praw diecezji włocławskiej, Torun 1932, pp. 47-48. The author could not be more convincing in relating to the time when this account was made.

72 "Ouch der bisschof hot deme meister deme Got genode czu iore an sente Petri und Pauli tag czu Thorun of deme huse in syme gemache mit ofgeracten henden und mit weynenden oughen gesworen undgelobete bei Gote und bei synen truwen und bey seynen eren weder den orden nymmer czy syn, dy weyle her lebete, sondir alle truewe und libe czu irczeighen in worten und in wercken [...]" (GStAPK, OF, no. 276, ch. 129). As it was reiterated on numerous occasions by the author of the account, the bishop failed to meet the commitments he had made to the Order.

73 "Ouch noch der vorbindunghe vurthe der meister den bisschof mit syner hand us syme gemache in das somerhaws kegen der Wyessel; do was der gancz rot des ordens ynne bey enandir und sagete alle dy ding deme rate und gar fruntlichen enpfing der rat den bisschof [...]" (ibid., ch. 129v).

${ }^{74}$ Recent study suggests that the nomenclature of medieval, Teutonic records referring to castle construction, German noun "gemach" was used to denote larger, detached buildings (residential or utility facilities), or floors in larger interiors, cf. S. Jóźwiak, J. Trupinda, Krzyżackie, p. 109 f.

${ }^{75}$ For the probable location of the commander's "gemach" cf. further. 
it to the western part of the outer castle and turned south towards the Vistula. However, it cannot be precluded that during his visit in June 1410, the Grand Master was residing in a different "gemach," and the $15^{\text {th }}$ century written records provide evidence for many such places within the outer castle. ${ }^{76}$ The foundations of $14^{\text {th }}$-century residential and utility facilities located along the western defensive wall of the outer castle (in the direction of the Old Town of Toruń) were uncovered by archaeologists a long time ago. ${ }^{77}$ Therefore, if the "gemach" in which the Grand Master was residing was located in any of them, the superior of the Teutonic Order together with the bishop would also have headed south. And that is where (along the southern wall of the outer castle) archaeologists uncovered the remains of facilities whose purpose has not been yet determined. ${ }^{78}$ This is the place where the "summer house" might have been located.

What is known about other developments of the outer baileys and the outer castle from medieval written sources? The inventory list of the Torun Castle drawn up on 25 December 1384 included 720000 bricks registered in stock of this administrative unit. The subsequent list of that type, from 30 November 1392, contained information about objects (chiefly weapons) stored "im nuwen gemache."79 There is no reason to doubt that this expression refers to the newly built commander's "gemach" from the late 1380s. Expressis verbis it was listed in the inventory list of $1436 .{ }^{80}$ However, how can we know that it was located in the outer castle or the outer bailey $?^{81}$ All the doubts are dispelled by the content of the charter containing a judgement passed by the Commander of Torun and the Commander of the Castle, as well as two councillors in a dispute between the Old and the New City of Torun regarding the rent for the altaria of the Holy Cross from St. John's Church. The document was issued on 9 April 1439 "in suburbio castri Thorun et in comodo venerabilis et religiosi viri domini Conradi de Erlischuwsen commendatoris dicti castri, ${ }^{82}$ that is in the commander's living quarters ${ }^{83}$ located in the outer castle (or outer bailey), which undoubtedly refer to his "gemach." ${ }^{84}$ Where

${ }^{76}$ More on the subject (further).

${ }^{77}$ These findings are collected and commented upon by Bogusz Wasik, cf. idem, op.cit., pp. 250-251.

${ }^{78}$ Z. NAWrockI, op. cit., pp. 20-21. Bogusz Wasik assumed that these facilities were erected between the end of $13^{\text {th }}$ century and the first quarter of the $14^{\text {th }}$ century, cf. B. WASIK, op. cit., pp. 249-250.

${ }^{79}$ G.A., p. 429.

80 "Das kompthurgemach" (ibid., p. 447).

${ }^{81}$ A thorough analysis of medieval written records as regards the stronghold of Malbork has shown that all the facilities within its defensive walls, except for the high castle, were located in the outer castle, cf. Sławomir Jóźwiak, Janusz Trupinda, Organizacja życia na zamku krzyżackim w Malborku w czasach wielkich mistrzów (1309-1457), Malbork 2011 (ed. 2), pp. 71-85.

${ }^{82}$ APT, Kat. I, no. 918.

83 "Commodum" - living quarters, flat, room, floor - see M. PLEZIA, Stownik, vol. 2, p. 684.

${ }^{84}$ How important is the proper understanding of the nomenclature presented above, which was used in medieval written records, for the knowledge of topography and spatial layout of the Commander's High Castle and the outer castle becomes evident when we consider serious interpretational 
exactly was this facility located? The most important source that contains the answer to this question is the letter that the Commander of the Torun Castle wrote to the superior of the convent at the beginning of January 1420, which has already been quoted above, accounting the course of the fire in the stronghold and the incurred losses. The fire reportedly consumed the development (referred to in the records as "dy kammer") from the commander's "gemach" to the tower. The fire consumed oat supplies and beaver hide belonging to both superiors of the convent, as well as bedclothes and other equipment belonging to the tailor. ${ }^{85}$ In all probability the tower in question was the main castle tower. ${ }^{86}$ Therefore, the commander's "gemach" which was quoted in the records must have been located in the northern part of the western outer bailey of the Torun High Castle. ${ }^{87}$ In these circumstances there is very little left to do but look for the utility facilities that were burnt down in 1420 in the ground floor of the western (and partially northern) wing of the convent in the vicinity of the tower.

In other sources from before 1450s, the location of the commander's "gemach" was either presented vaguely or not at all. The vidimus of Władysław Jagiełło’s document of 8 May 1419 was drawn up by Gerhard Stolpmann, the Bishop of Pomesania, and Jan Marienau, the Bishop of Chełmno, on 12 June 1419 "in suburbio castri Thorun Culmensis diocesis." 88 There is a possibility that this general definition of an object within the outer castle or the outer bailey of the High Castle might have referred to the commander's "gemach." On the other hand, in the already quoted description of negotiations held on 18 December 1433 between the representatives of the state and the Grand Master and his dignitaries regarding peace

errors made by a German scholar, Arthur Semrau, in his otherwise rather detailed studies of the Torun Castle. Even though he was well versed in the numerous (although not all) sources, including visitation protocols from the period of 1442-1446, he came to the conclusion that what should be understood under the definition of the castle proper ("rechtes Haus") is only the southern wing of the entire layout (triangular, of which fact the author had not yet been aware) of the High Castle. All the other facilities with the exception of the castle, including the remaining wings (two) of the main house were to be situated, in accordance with his conception, in the outer castle ("vorburg"). The confusion that ensued after A. Semrau's suggestion was additionally strengthened by the fact that he assumed an erroneous translation of the word "gemach," which appeared in the medieval written sources in the area in question, by which he understood one of the wings (on the northern or southern side) of the High Castle, cf. A. Semrau, Das Ordenshaus Thorn, pp. 62-65. And for his interpretation of the other facts and written records to be fairly correct and logical, it would be enough for A. Semrau (in line with the logics of his initial assumptions) to assume that the High Castle in Torun comprised of several wings of the main layout (not only of one southern wing).

${ }^{85}$ GStAPK, OBA, no. 3094; Acten, Bd. 1, no. 283.

${ }^{86}$ More on the subject, cf. above.

${ }^{87}$ In his most recent book, Tomasz Torbus (without taking into account the written records analysed herein), by citing Z. Nawrocki's work, pointed out to the possibility that the "commander's house" might have been situated in the development of the southern side of the western outer castle, cf. T. Torbus, Zamki, p. 66. The problem is that in the article by Z. Nawrocki that he quotes there is no mention of the "commander's house" or its location, cf. Z. NAWrockI, op. cit., pp. 7-72.

${ }^{88}$ GStAPK, Perg. Urk., Schiebl. 65, no. 28. 
with Poland, to be found in the "Older Chronicle of Grand Masters," the venue where the talks were held was described in following words: "[...] das wolten dy landt zw Prewssen nicht zwlassen ghen und hetten sych gemeniglich zwsamen verbot ghen Thoren und gyngen auff das slosse zw dem hoemeyster und seynen gebitigern auff des komethurs gemach [...]" ${ }^{99}$ The lack of precision from the author of the account might have been caused either by his inadequate knowledge of the castle's topography, or a tendency, which was then already visible following the example of Malbork, to standardise terminology so that the term "castle" extended to all its parts (together with the outer bailey and the outer castle). ${ }^{90}$

Undoubtedly, the Commander of Torun had a chapel at his disposal in his "gemach." However, proving this fact requires a far broader analysis of the sources. We have already cited a fragment from March 1263 on the progress of works on the convent church (located on the floor, in the eastern part of the southern wing of the High Castle). In the account written in Latin it was also referred to as the "capella," yet subsequently, in German language sources, it was invariably referred to as the "kirche." However, the inventory list of the Torun Commandry of 4 April 1410 includes information about an altar in the chapel ("capelle") of the convent superior. ${ }^{92}$ Considering the nomenclature used for temples in other commander castles in the State of Teutonic Order in Prussia in early $1400 \mathrm{~s},{ }^{93}$ there is no doubt that a private chapel of the superior of Torun's convent was referred to. The chapel was situated in his "gemach," which was built between 1384 and 1388, and located in the northern part of the western outer bailey of the High Castle. ${ }^{94}$

Perhaps in the nearest vicinity of the commander's seat referred to above, the "gemach" of the Commander of the Torun Castle was located, which was first mentioned expressis verbis in the inventory list of 31 October 1428 mentioned above. ${ }^{95}$ Such a location would be dictated by the common practice of using the word "gemach" in relation to Teutonic castles in the nomenclature of written sources prepared in German in the State of the Teutonic Order in Prussia of that time. ${ }^{96}$ On account of the fact that the castle commander acted on behalf of the commander (who was often away) as the superior of the convent, it is more likely that his "gemach" was located among the buildings in the northern part of the western

${ }^{89}$ Die ältere Hochmeisterchronik, p. 638.

${ }^{90}$ More on the subject: S. Jóźwiak, J. Trupinda, Organizacja, pp. 83-85.

${ }^{91}$ Cf. iidem, Krzyżackie, pp. 294-297.

92 "[...] item 1 gancz messegerethe mit aller czugehorunge czum alter in des kompthurs capelle" (G.A., p. 433).

${ }^{93}$ More on the subject: S. Jóźwiak, J. TrupindA, Krzyżackie, pp. 177-184, 294-305.

${ }^{94}$ Arthur Semrau also thought that the extract of 1410 referred to the commander's chapel, which should be linked to his "gemach," yet, the scholar failed to accurately locate the latter, cf. A. SEMRAU, Das Ordenshaus Thorn, p. 61.

95 "Hawskompthurs gemach" (G.A., p. 442). Yet however, against A. Semrau's suggestion, none of the information about it is present in the source from 1420 analysed above, cf. A. SEMrAu, Das Ordenshaus Thorn, p. 64.

${ }^{96}$ See footnote 74. 
outer bailey of the High Castle, than in the facilities located along the western defensive wall of the outer castle. However, there is no indication when the "gemach" was erected. Its existence is not yet confirmed in the notarial instrument that presents the circumstances of sending a letter of declaration on 11 of August 1409 to the Polish Burgrave of Złotoria, whose preparation was ordered by Henryk Holt, the Torun Castle Commander, on 31 October 1409. The document was issued "in castro Thorun Colmensis dyocesis in habitaculo venerabilis domini Heynrici Holt vice commendatoris ibidem." ${ }^{\prime 7}$ It is not transparent from its content that the room (chamber, building) ${ }^{98}$ of the Torun Castle Commander was then located in the outer castle, but this may also be due to an inconsistent use of terminology by the notary responsible for the preparation of the document.

However, the "gemach" is mentioned in a fragment of a larger account from around 1453, in which Daniel Konitz, a merchant from Toruń, reported (to the council of the Old City of Torun'?) the course of his conflict with the Teutonic head of the mint, Jan von Lichtenstein, which had been going on since 1449. One of the scenes of the conflict took place in the "gemach" of the Torun Castle Commander (in the presence of this official), where Lichtenstein demanded that Konitz should return him 100 grzywnas. ${ }^{99}$ Unfortunately, this account also lacks indications as to the precise location of this facility.

Interesting information was contained in the notarial transumpt, drawn up on 13 December 1435 at the request of the Commander Walter Kirskorf, which contained a copy of king Władysław Jagiełło's document from 27 May 1426, wherein the monarch gave permission to religious authorities to rebuild a previously demolished mill in Lubicz on the river Drwęca. The transumpt was prepared "in estuario domus procurato[ris de Ko]nigsberg in suburbio castri Thorun." ${ }^{100}$ In Latin nomenclature the term "procurator from Königsberg" unmistakably referred to the great steward. ${ }^{101}$ It would follow from the quoted source record that this Teutonic official, who specialises in trade, had a seat ("domus") in Torun outer castle. What is more, it contained a heated room for representative purposes ("estuarium"). Such a conclusion could be favoured not only because of the name of the room but also the time at which the document was issued (mid-December). The information included in the earlier written records in fact confirms the fact

${ }^{97}$ Krzysztof KwiatкооwsKi, Okoliczności wypowiedzenia wojny królowi polskiemu Władysławowi II przez wielkiego mistrza Zakonu Niemieckiego Ulricha von Jungingen w sierpniu 1409 roku, ZH, vol. 74: 2009, no. 3, Source appendix, p. 32.

98 "Habitaculum" - living quarters, a utility building, room, chamber - cf. M. PLEZIA, Słownik, vol. 4, pp. 694-695.

99 "Ouch sprach her dornoch eynes andern tages in des hawskumpthurs gemach vor deme herren hawskumpthur, wulde got, das her noch von mir hette tawsunt mark prewsch, her welde is aller behalden noch sulde em doran nicht genugen [...]" (APT, Kat. I, no. 1420).

${ }^{100}$ GStAPK, Perg. Urk., Schiebl. XIX 14. The authors would like to express their gratitude to Prof. Adam Szwed of Nicolaus Copernicus University in Torun for providing this source.

${ }^{101}$ Cf. S. Jóźwiak, J. Trupinda, Organizacja, pp. 297-302. Earlier literature on the subject is also found there. 
that this Teutonic official, who was specialising in trade, had his own permanent seat within the Commander's stronghold in Toruń. On 9 December 1423, "in the Toruń Castle in our "granary»" 102 the steward of Königsberg, Hans von Moos, concluded a settlement with Bertold, the commune head of Inowrocław, regarding the splitting of his debt of 267 grzywnas into instalments. ${ }^{103}$ In all likelihood, the same facility (this time referred to as the "gemach"), was located within the Torun castle area, was cited six times in the records of Königsberg stewards, starting from the year 1400. It was used for storing numerous goods that belonged to these officials. ${ }^{104}$ It unmistakeably follows from the quoted transumpt of 13 December 1435 that the construction was located in the outer castle. The confirmation of this fact is present in the next source extract. Namely, a notarial instrument, issued on 20 December 1435 at the request of the Great Commander, Walter Kirskorf, and containing a copy of the document belonging to Salomea, the Princess of Kuyavia in 1292, was drawn up "in estuario domus procuratoris de Mariemburg in suburbio castri Thorun." ${ }^{105}$ Again, the text refers to the offices ("domus") of the steward located in Torun outer castle, but this time the steward of Malbork. However, considering the conclusions from the analysis carried out above, as well as the fact that the post of the steward of Königsberg was filled until 1440s in the least, whereas the analogical post in Malbork was liquidated directly after $1429,{ }^{106}$ one may presume that the notary who was drawing up this notarial instrument made a mistake, as he in fact meant Torun offices of Königsberg stewards. With current knowledge it is difficult to point to a different location than one of the facilities situated along the defensive wall of the western outer castle.

The "gemachs" mentioned above were not the only ones that were located within Torun outer bailey or outer castle. In a letter of 7 July 1422, the Commander of the Castle notified the Grand Master, Paul von Rusdorf, about a feud with the representatives of the Old Town over the possibility to elevate the tower located in the defensive wall "czwischen der Aldenstat und dem vorburge kegin des munczemeisters gemache obir."107 This record would point to the outermost (second) city wall, west of the outer castle. In this situation, the mentioned "gemach" of

102 "[...] czu Thoren uff dem husze in unser schefferey."

${ }^{103}$ Handelsrechnungen des Deutschen Ordens, hrsg. v. Carl Sattler, Leipzig 1887, pp. 315-316.

${ }^{104}$ Ibid., p. $103 \mathrm{f}$. Additionally, a list of equipment and goods stored in the "granary ("scheffereen") in Torun'" prepared in 1430 was also preserved. Particularly noteworthy is the tub in the baths listed towards the end ("item 1 fanne in der batstoben"), see GStAPK, OBA, no. 27940. Would the steward of Königsberg have had at his disposal his own baths in the offices located in the outer castle?

${ }^{105}$ GStAPK, Perg. Urk., Schiebl. 58, no. 25. The issuers of the Diplomatic Code of Warmia mentioned this notarial instrument in the form of a regesta, which in their view was to be issued "in suburbio castri Thorun", which is a serious and unjustified abridgment of the actually used formulation of the place where it was drawn up, cf. CDW, Bd. 4, hrsg. v. Viktor RöHrich, Franz LiedtKe, Hans SCHMAUCH, Braunsberg 1935, no. 607.

${ }^{106}$ Cf. Jürgen SARnowsky, Die Wirtschaftsführung des Deutschen Ordens in Preußen (1382-1454), Köln-Wien 1993, p. 99.

${ }^{107}$ GStAPK, OBA, no. 3808. 
the Teutonic head of the mint (Münzmeister) would also have had to be located in a relatively close vicinity, which was emphasised in the source text, to the disputable fragment of city fortifications, most probably in the complex of facilities adjacent to the western wall of the outer castle. An additional clue as to its location is found in a letter from the "Münzmeister" of Torun ${ }^{108}$ to the Grand Master, Ludwig von Erlichshausen, dated 23 September 1453. In the letter, the Teutonic official described the hostile attitude of the burghers of the Old City of Torun. They manifested their hostility by blocking the gate to the "gemach" in the vicinity of the High Castle ("am haws"). ${ }^{109}$ It follows from the context of the information contained in this source text that this structure must have been located in the outer castle, adjacent to the area under the jurisdiction of the self-government authorities of the Old City of Torun. Such topography is reconstructible. It is otherwise known, however, that the mint (not to be confused with the "Münzmeister's" "gemach") was located in the Old City of Toruń, in direct proximity of the western outer castle, in Promowa (modern-day Mostowa street), in its north-west frontage (north of modern-day Ciasna street). ${ }^{110}$ Archaeologists, on the other hand, point to the fact that exactly at this level, in the outermost western wall of the outer castle, there was a gate tower (the third one in a row of towers looking from the south) leading towards the Old Town. ${ }^{111}$ This tower was probably referred to in the "Münzmeister's" letter of 1453. Thus the cited facts corroborate the location of the "gemach" of this Teutonic official within the outer castle, by its western defence wall. This structure had already been mentioned in 1505 , on the occasion of a pledge being paid by the Polish side for Dobrzyń Land. ${ }^{112}$

Another riddle, as far as the topography of the outer castle development is concerned, appears in the list of complaints lodged by Teutonic Knights in 1453 about hostile actions taken by their own subjects against the Order and its authorities. Beyond doubt it was drawn up for the purpose of the trial held before the

${ }^{108}$ On the Teutonic heads of the Torun mint, cf. Żaneta Bonczkowska, Mennica torunska od drugiej połowy XIV wieku do 1454 roku. Lokalizacja - personel - funkcjonowanie, Toruń 2011, p. 33 f.

109 "[...] sunder dy knecht, dy ich alnacht in der munczen ligen haben mus, dy sagen mir, dy sy al nacht wachen starck czwischen der muncz und dem hawse ein partey vor mitternacht, dy ander dar nach und dy ketten und dy sleg am thor an beiden seitten slissen und ein thoringe habt an meim gemach am haws czu gmacht haben lassen, daz in mancheim jar ny gmacht ist und alle nacht ez beman, dez doch vor ny getan haben" (GStAPK, OBA, no. 12402).

${ }^{110}$ Summary of the knowledge on the subject so far: Ż. BоNCZKowska, op. cit., pp. 15-22. Literature provides information from numerous scholars on the existence of a "Mint Gate," from the first half of the $14^{\text {th }}$ century, which was located in the south-eastern corner of the outer castle wall, cf. T. Torbus, Die Konventsburgen, p. 682; Z. NAWrocki, op. cit., pp. 23, 32, 45; B. WAsiK, op. cit., p. 251. The name of the gate, however can't have originated in the Middle Ages, as the "Münzmeister's" "gemach" and the mint itself were located in a different spot at that time.

${ }^{111}$ Summary of the knowledge on the subject so far: B. WAsIK, op. cit., pp. 247, 250-251.

112 "Item 1/2 m., das golt und silbir, das von des landes wegen Dobryn und Slotterye quam, in das monzmeisters gemach zu tragen" (Das Marienburger Tresslerbuch der Jahre 1399-1409, hrsg. v. Erich JoACHIM, Königsberg 1896 (further cit. M.Tr.), p. 354). 
Imperial Court. The source text contained information which has otherwise been unknown, that the self-government authorities of the Old City of Torun claimed the right to a certain stretch of the curtain wall "by the castle" (in fact what they meant was a certain stretch of the outer castle fortifications), together with a nondescript tower and a gate, where a small room ("stobechen") belonging to the commander was located. The Teutonic author of the complaint denied these claims arguing that the founders and former builders of the castle clearly knew why they had erected the enclosing wall and the gate. ${ }^{113}$ Whereabouts within the area of the Torun stronghold should they be sought after? Perhaps what was meant was the outermost northern curtain wall of the western outer castle (adjacent to the Old Town), of which there is not much known today.

However, there is no doubt that from mid-14 $4^{\text {th }}$ century (or even earlier) the number of residential and utility facilities in the outer castle, predominantly in its western part, started to rise. This is corroborated by general sources. If Ludwig von Erlichshausen, the Grand Master, in July and August 1452, hosted king Kazimierz Jagiellończyk and Polish dignitaries in Torun outer castle, ${ }^{114}$ then there must have been facilities where they could dine together. Sources containing information about the fate of the outer castle development during the siege held by the troops of the Prussian Confederation of 7 February 1454, yet the details were divergent. A letter sent on the same day by the representatives of knighthood and towns from Toruń to Gdańsk council, contained the information that before the Teutonic garrison surrendered, the (High) Castle was fired at and the entire outer castle was burnt down. ${ }^{115}$ The protocols of the Torun town council, which referred to those events, were accounted for in a different manner. Namely, the castle had been besieged since the afternoon from all possible directions (the Old and the New Town and the lhota). Before surrendering (around midnight) the besieged managed to set fire to the outer castle (to what end?). ${ }^{116}$ Yet a different account of the matter was provided by the incarcerated Teutonic Knights from the castle garrison (with the leadership of the Commander) in a letter of 11 February 1454 to the Grand Master. According to this letter, on the 7 February the siegers attempted to crush the walls of the outer castle (the direction of the attack, however, is not known), and subsequently they had the "gemachs" ("dy gemecher") located in that

113 "Item die in der alden stad sprechen, das die muwer am hawße mit dem thore und dem thorme, do des kompthurs stobechen ynne ist, gehoret zcur stad und nicht zcum hawße; mit welcher gerechtikeyt sie das vornemen, konne wir nicht gewissen. Wir getruwen, das die alden herren, die das haws uffgeleget und gebuwet haben, is also weyt gewest seyn, das sie dem hawße eyme rinckmawer und eyn thor haben behalden" (Zentralarchiv des Deutschen Ordens, Wien, Hs 133, fol. 105v).

114 "In diesen Jahre hatte König Casimirus zu Pohlen den Herrn Hohemeister Ludwig v. Erlichshausen auf dem Schlosse zu Dybow am tage S. Jacobi; darnach am nechsten Sontag war der König des Hohmeisters Gast auf dem Schlosse zu Thorun in Vorburg nebst vielen Praelaten von beyden Theilen" (Thorner Denkwürdigkeiten von 1345-1547, hrsg. v. Albert VoigT, Mitteilungen des Coppericus-Vereins für Wissenschaft und Kunst zu Thorn, Bd. 13: 1904 (further cit. Thor. Denk., p. 71).

115 "[...] sunder das hus ist zere czuschossen und das vorborge al vorbrant" (Acten, Bd. 4, no. 185).

116 "In der nacht brandten sie die vorburg selber aus [...]" (Thor. Denk., p. 73). 
castle area set fire to. ${ }^{117}$ In the light of the analyses above one may gather that they referred to residential facilities and buildings used for representative purposes located in the western and north-western part of the outer castle. However, the information contained in the cited sources cannot be used to determine which of the conflicted sides was responsible for setting the fire.

Certainly, the entire outer castle area of the Torun Castle abounded in utility facilities. One should agree with A. Semrau, that the context of the mention in the inventory list of Torun Commandry of 6 November 1446 points to the location of the castle bath in the outer castle (the question arises, however, where exactly). ${ }^{118}$ The same is indicated by the information contained in the register of income and expenditure of this administrative unit for the years 1447-1448, drawn up in 1449. ${ }^{119}$ The location of the infirmary within the area of the Torun Castle, however, is not that straightforward anymore. It appears in written records for the first time in the "Book of the Malbork Treasurer" in 1405. ${ }^{120}$ In a letter of 10 October 1445 the Commander of Torun pleaded with the Grand Master on behalf of brother Sparnecker, who was in his convent at the time, to refer him to the infirmary in the Gdańsk Castle, and if that were not promptly possible, to trust him with the post of a gate administrator ("thorampt"), where he could wait until the death of one of the persons occupying the infirmary. Then he could take his place. ${ }^{121}$ It appears that the said Sparnecker achieved his goal, as in the visiting report of the Gdańsk Commandry of 14 November 1446, Ditmar von Sparnacker was among the four Teutonic Knights listed in that infirmary. ${ }^{122}$ In another letter to the chaplain of the Grand Master, Andrew Santberg, of 23 April 1453 the Commander of Torun announced that Martin, a priest of his convent stays in the infirmary of his castle due to sickness and general weakness. There is not, however, much hope for his recovery, unless he was transferred to a different convent and a better infirmary. If so, his condition might have improved. ${ }^{123}$ The source information above confirms the fact that a separate space for sick members of the Order existed somewhere within the castle discussed here (the question remains where it was located). What also follows from these sources is that the infirmaries of some other Teutonic castles enjoyed a better renown, as one had to wait until a bed was available. Recent studies over other Teutonic strongholds In Prussia indisputably point to the fact that most infirmaries in the second half of the $14^{\text {th }}$ and the first half of the $15^{\text {th }}$

117 " [...] sy iczczund faste liszen hauwen buszen an den mauwern und liszen dy gemecher im vorburge entczunden” (Acten, Bd. 4, no. 193).

118 "Karban: item 8 pferde, item 6 ochsen, item 2 briefsweyken, item 3 exe; im schirrehofe 1 kessel, in der badstoben 1 ax" (G.A., p. 459; A. Semrau, Das Ordenshaus Thorn, pp. 62-65).

119 "Vorbuwet im hofe an den schoppen, stalle, badestoben und an der walkmolen" (M. BISKUP, Materialy, p. 159).

120 "Item 2 m. eyme herren in der firmarien zu Thorun gegeben [...]" (M.Tr., p. 339).

${ }^{121}$ GStAPK, OBA, no. 8932.

${ }^{122}$ Visitationen, Teil 1, no. 125, pp. 277-278.

${ }^{123}$ GStAPK, OBA, no. 12145. 
centuries were located within the outer castle. ${ }^{124}$ It could not have been otherwise in Torun. ${ }^{125}$

The Commander's Castle discussed herein is one of the few strongholds of the State of the Teutonic Order, where the preserved written records allow an exceedingly accurate location of each armoury within the spatial layout. The inventory list of 20 January 1381 includes a mention of two places where weapons (ranged and defensive) were stored: in the convent proper ("off dem huse") and in the tower ("off dem torme") in the courtyard of the High Castle. ${ }^{126}$ In 1392, that is after the Commander's "gemach" had been built in the north western outer bailey, ${ }^{127}$ three armouries were mentioned in the records: in a chamber in one of the wings of the convent proper ("in der kamer off dem huse"), in some separate room in the Commander's new "gemach" ("im nuwen gemache") and in the tower ("off dem grosen torme"). ${ }^{128}$ Most probably the armoury located within the development of the Commander's seat ("gemach") was mentioned in the letter that has already been quoted, sent to him by his deputy at the beginning of January 1420. Since the fire consumed that area of the castle (where the chambers with supplies were) which extended between the Commander's "gemach" and the tower. However, the Teutonic official reassured his superior that his seat and the weaponry ("harnisch") were unscathed. ${ }^{129}$ As mentioned above, the fire damaged only the ground-floor development of the northern part of the eastern wing of the High Castle, therefore one may conjecture that the source could only have referred to the armoury in the Commander's "gemach." The inventory list of this administrative unit drawn up on 6 November 1446, featured information about a "gunpowder chamber" ("pulverkamer") within the stronghold discussed here, however, its location is yet unknown. ${ }^{130}$

The same letter of the Torun Castle Commander from the beginning of 1420 also mentions that the tailor's bedclothes and equipment were destroyed in the fire too. ${ }^{131}$ As it has been established above, the northern part of the western ground-

${ }^{124}$ S. JóźWIAK, J. Trupinda, Krzyżackie, pp. 185-202.

${ }^{125}$ Scholars so far have identified the alleged "hospital" in a building located north-east of the High Castle. The erection date was presumably $14^{\text {th }}$ century, cf. Z. NAWrocKI, op. cit., p. 24; B. WASIK, op. cit., p. 249. It would be very tempting to locate the castle infirmary here. Regrettably, there is no solid evidence that it was in this particular building.

${ }^{126}$ G.A., p. 427.

${ }^{127}$ More on this facility, cf. above.

${ }^{128}$ G.A., p. 429.

129 " [...] so thu ich euch czu wissin, das von euwirm gemache bis an den thorm, do vorath off leit, dy kammer gancz abgebrant sint; ydoch an euwirm harnisch noch gemache keyn schade ist gescheen [...]" (GStAPK, OBA, no. 3094; Acten, Bd. 1, no. 283).

${ }^{130}$ G.A., p. 460.

131 "Keynen andern schaden von der gotis gnaden habe wir ent[pfangen, allein deme] schroter seyne bettecleydir sint vorbrant unde ander seyn gerethe [...]" (GStAPK, OBA, no. 3094; Acten, Bd. 1, no. 283). Arthur Semrau signalled an error made by the publisher of this source, M. Toeppen, in the interpretation of a key word. He believed that the noun "schroter" should have really been 
floor wing of the High Castle was destroyed, however, it is not entirely certain whether the tailor's living quarters were located there, or merely storerooms with clothes that were under his management.

Only one written source from the epoch gives an account of a lavatory tower ("danzker") in the Commander's Castle in Torun. The inventory list of that administrative unit prepared on 6 November 1446 on the occasion of counting firearms stored within the stronghold, contained one mention of a section on the "dansker." 132 It is beyond doubt that the mentioned structure referred to the lavatory tower built over a stream and connected through a porch with the western wing of the High Castle, which has been preserved until this day. Researchers agree that in the tower in its present shape was erected in the first half of the $14^{\text {th }}$ century. ${ }^{133}$ Thus it is not known what the original sanitation facilities built in the second half of the $13^{\text {th }}$ century in the Torun Castle looked like.

The inventory list of the Commandry prepared on 31 October 1428 also includes four mills, two of which were to be located in the outer castle ("von dem hawse"). ${ }^{134}$ This information is corroborated in the summary of revenues and expenditure of the Torun Commandry for the period of 1447-1448, prepared in 1449 presumably as a result of a visitation. It follows from the list that four mills were in operation to satisfy the needs of the castle, two of which were located in the outer castle. ${ }^{135}$ This observation is also corroborated by a fragment of a document drawn up on 25 February 1464 (i.e. after the castle had been put down) by Kazimierz Jagiellończyk. In the document the monarch secured the sum of 50 gold Hungarian florins that he owed to a burgher of Torun, Jan Trost, on the four mills, two of which were found within the area of the demolished castle (i.e. in the outer castle). ${ }^{136}$ One of them had existed since 1262, which follows from the document of Helmerich von Würzburg cited above. ${ }^{137}$ It was then located "by the castle," that is in the later outer castle.

\footnotetext{
"schriber" (a writer), cf. A. Semrau, Das Ordenshaus Thorn, p. 56. However, following a thorough analysis carried out by the authors of this article on the originally preserved written source, makes it absolutely clear that M. Toeppen was much closer to the truth. The interpretation of that word is difficult indeed, but one may state that its final four letters do not contain " $i$ " or "b," which leads to the conclusion that the noun "schreiber" suggested by A. Semrau must be rejected.

132 "[...] item 1 steynbuchse uffim danczk" (G.A., pp. 458-460).

${ }^{133}$ Summary of the knowledge on the subject so far: T. Torbus, Die Konventsburgen, pp. 680-681; idem, Zamki, p. 64; B. WASIK, op. cit., pp. 247, 252.

${ }^{134}$ G.A., p. 442.

135 "Us der Tripsmole, der Neuwenmole und den molen vor dem hawße von malcze 30 mr., 2 sc." (M. Biskup, Materiaty, p. 151). The Toruń Commander, Jan von Beenhausen, mentioned the four mills in the letter to the Grand Master on 7 March 1446 (GStAPK, OBA, nr 9060). Arthur Semrau assumed that one of them was located north of the lavatory tower, and the other south of it, yet he did not provide any evidence to support his conjecture, cf. A. SEmrau, Das Ordenshaus Thorn, p. 57.

136 " [...] confirmari super quatuor molendina, quorum duo in ciuitate Thorunensi infra arcem, quae destructa est [...]" (APT, Kat. I, no. 2661).

137 “[...] von der mulen under der burch ze Thorun” (APT, Kat. I, no. 5; Pr.Ub. I/2, no. 156).
} 
In conclusion of the analysis conducted above it should be noted that the information contained in medieval written sources contributes significantly to the knowledge of the Torun Castle, which was torn down in 1454. The erection of the defensive walls, to a degree which is hard to be precisely pinpointed, had started in 1255 . By 1262 , the stronghold in its original shape had already been up and running. The following year (1263) saw progressing works on the erection of some of the interiors (at least the chapel which was in all likelihood located on the floor of the eastern part of the southern wing). It was not uncommon to find information in medieval written sources (but only from 1381) about the main, octagonal tower, located in the northern part of the High Castle's courtyard. However, it must have been erected earlier.

Information on the facilities located outside the main area of the High Castle, which appears in the analysed accounts, is of particular historical interest. These include: the Commander's "gemach" (along with the chapel, refectory and the kitchen) in the northern part of the western outer bailey, the Castle Commander's "gemach" - presumably in the vicinity (however, it was erected later, perhaps after 1409), and the summer house ("somerhaws") with a summer chamber ("aula estivalis"), which had existed at least since 1380s and were located probably in the southern part of the western outer castle. Other available medieval written records mention the following other facilities: the "gemach" of the Teutonic head of the mint ("Münzmeister") located by the western defensive wall of the outer castle, which is dated at the end of $14^{\text {th }}$ century. the "gemach" ("domus") of the steward of Königsberg, which was located in the undefined, yet probably also western part of the outer castle, as well as the infirmary which might have been situated (which is not certain) in the north-eastern part of the outer castle. The topography of the castle also abounded in utility facilities. For example, at least two mills were located within the defensive walls, presumably in the eastern part of the outer castle. In conclusion, the analysed medieval written sources provide a picture of a complex development of the Torun Castle.

(transl. by Agnieszka Chabros)

Received $28^{\text {th }}$ April 2016

Received in revised form $28^{\text {th }}$ October 2016

Accepted $31^{\text {st }}$ October 2016

Prof. dr hab. Sławomir Jóźwiak

Institute of History and Archive Sciences

Nicolaus Copernicus University in Torun

e-mail:sj@umk.pl

PhD Janusz Trupinda

Historical Museum of the City of Gdańsk

e-mail: j.trupinda@mhmg.pl 
[465] Topography and spatial layout of the castle of the Teutonic commander in Torun...

\section{TOPOGRAFIE UND RÄUMLICHE ANLAGE DER KOMTURSBURG DES DEUTSCHEN ORDENS IN THORN IM LICHT SCHRIFTLICHER QUELLEN AUS DEM MITTELALTER}

\section{Zusammenfassung}

Schlüsselwörter: Mittelalter, mittelalterliche Architektur in Preußen, Deutscher Orden, Preußen, Deutschordensburgen, Burg

Die in schriftlichen mittelalterlichen Quellen enthaltenen informationen bereichern das Wissen über die 1454 zerstörte Stadtburg von Thorn wesentlich. Der Bau eines schwer einzugrenzenden Teils der umgebenden Verteidigungsmauern (aus Stein) begann spätestens 1255. Schon 1262 bestand die Festung in einer einfachen Form. Im Jahr darauf (1263) fanden Arbeiten an der Errichtung einiger ihrer Innenräume statt (oder zumindest an der Kapelle, die sicherlich von Anfang an im ersten Stock im östlichen Teil des Südflügels untergebracht war). In mittelalterlichen schriftlichen Quellen wurde häufig (allerdings erst ab 1381) der achteckige Hauptturm erwähnt, der im Nordteil des Hofs der Hochburg stand. Er war allerdings zweifellos früher errichtet worden.

Besonderes Interesse erregen die in den analysierten Überlieferungen erscheinenden Informationen über Objekte, die sich außerhalb des Raums der Hochburg befanden. Dazu gehören: ein "gemach" des Komturs (mit Kapelle, Remter und Küche) im Nordteil des westlichen Parchams, ein "gemach" des Schlosskomturs, das sicher in der Nähe lag (allerdings später entstand, vielleicht nach 1409) sowie ein "somerhaws" mit einem "Sommersaal" ("aula estivalis"), der mindestens schon seit den 80er Jahren des 14. Jahrhunderts bestand und höchstwahrscheinlich im Südteil der westlichen Vorburg gelegen war. Unter den anderen in mittelalterlichen Schriftquellen greifbaren Objekten ist auch das "gemach" des Münzmeisters des Ordens zu erwähnen, das an der westlichen Verteidigungsmauer der Vorburg lag, ebenso das seit Ende des 14. Jahrhunderts genannte "gemach" ("domus") des Tresslers von Königsberg, das sich in einem unbekannten, wahrscheinlich ebenfalls westlichen Bereich der Vorburg befand, und auch das Gebäude der Infirmerie, die im nordöstlichen Teil der Vorburg gelegen haben könnte (was allerdings nicht sicher ist). In der Topografie der Burg fehlte es auch nicht an Wirtschaftsgebäuden. Beispielsweise befanden sich innerhalb der Mauer mindestens zwei Mühlen, wahrscheinlich im Ostteil der Vorburg. Insgesamt ergibt sich also aus den analysierten schriftlichen mittelalterlichen Quellen das Bild eines komplexen Gebäudeensembles in der Burg von Thorn.

\section{TOPOGRAPHY AND SPATIAL LAYOUT OF THE CASTLE OF THE TEUTONIC COMMANDER IN TORUŃ IN THE LIGHT OF THE MEDIEVAL WRITTEN SOURCES}

\section{Summary}

Key words: the Middle Ages, medieval architecture in Prussia, the Teutonic Order, Prussia, Teutonic castles, castle

The information included in the medieval written sources enrich our knowledge about the Torun castle destroyed in 1454. The construction of the part of the defensive walls 
(made from stone?) lasted at least from 1255. In 1262 the stronghold in its original form had been already erected. In the subsequent years (1263) works took place to construct its interiors (at least a chapel located on the first floor in the eastern part of the southern wing). The main octagonal tower situated in the northern part of the courtyard of the High Castle was frequently mentioned in the medieval written sources (starting from 1381). However, it must have been erected earlier.

The information about buildings located beyond the space of the High Castle is particularly interesting. The buildings included the "gemach" of the commander (with a chapel, refectory and a kitchen) in the northern part of the western outer bailey, the "gemach" of the castle's commander - probably in the vicinity (it was created later - after 1409) and the "summer house" ("somerhaws") with the "summer hall" ("aula estivalis") existing since at least the 1380s and situated in the southern part of the western Low Castle. Among other buildings recorded in the medieval written sources there were also the "gemach" of the Teutonic head of the mint ("Münzmeister") located next to the western defensive wall of the Low Castle; the "gemach" of the steward of Königsberg (Kaliningrad, Russia) mentioned from the end of the $14^{\text {th }}$ century and situated probably in the western part of the Low Castle; the building of the infirmary which might have been located in the north-east part of the Low Castle. In the topography of the castle there were also outbuildings. For example, at least two mills were situated within the defensive walls probably in the eastern part of the Low Castle. To sum up, the medieval written sources present a picture of a complex construction of the Torun castle.

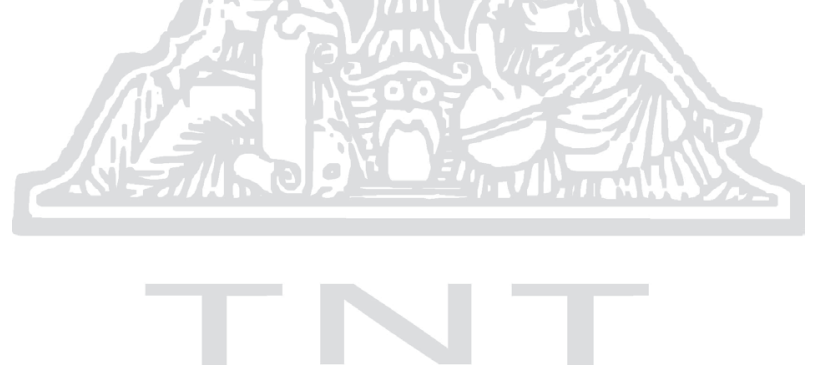

